\title{
SIGNIFICANCE OF FINANCIAL LITERACY FOR THE AGRICULTURAL HOLDINGS IN SERBIA ${ }^{1}$
}

\author{
Vladimir Zakić2, Vlado Kovačević ${ }^{3}$,Jelena Damnjanovićc
}

\begin{abstract}
Summary
The aim of this paper is to analyse the level and the significance of farmers'financial knowledge or literacy, as well to propose measures for the improvement of financial skills in agricultural holdings.

According to the paper's results, the level of farmers'financial knowledge is low; at the state level there hasn't been established satisfying financial education of farmers. It is necessary to establish continuous education programs in this field through agricultural extension services; at the state level, it is important to improve the coordination between different state bodies that conduct an educational program in agricultural sector, as well as the science research results and to make an educational material available to farmers.

When considering the significance of financial literacy, it is usually analyzed from the perspective of adult people. However, recent studies indicate the importance of increasing financial literacy already at the level of youth or children. This theoretical concept is currently being accepted in the activities of the Government of the Republic of Serbia. In this regard, the Ministry of Economy has decided to introduce entrepreneurship to primary school through numerous projects.
\end{abstract}

Key words: financial knowledge, extension service, finance models, agriculture.

JEL: $Q 14, I 22$

1 This paper is a result of the research projects No. 179028 - "Rural labor market and rural economy of Serbia - Income diversification as a tool to overcome rural poverty" financed by the Ministry of Education of the Republic of Serbia.

2 Vladimir Zakić, PhD, Associate Professor, University in Belgrade - Faculty of Agriculture, Nemanjina 6 Str. 11080 Belgrade-Zemun, e-mail: zakic@agrif.bg.ac.rs

3 Vlado Kovačević, PhD, Associate Researcher, Institute for Agricultural Economics, Belgrade, Serbia, e-mail vlado_k@iep.bg.ac.rs

4 Jelena Damnjanović, PhD, Professor, Novi Sad School of Business, Novi Sad, Serbia, e-mail: $\underline{\text { skola@ } @ \text { vps.ns.ac.rs }}$

EP 2017 (64) 4 (1687-1702) 


\section{Introduction}

Traditionally neglected sector of agriculture in Serbia got into the limelight of the media and economic experts during the period of current global economic crises, primarily because of the pronounced surplus of agricultural and food products in foreign trade ratio. However, agricultural export is generally related only to some products, such as cereals, fruit (raspberries) and sugar. This leaves room for significant improvement in foreign trade, both in scope and structure, where the the emphasis should be on processed products, which yields much higher profit ratio.

Agriculture, and especially the primary agricultural production, is characterized by a serious of specificities (seasonality and organic character, slow capital turnover etc.), due to which it is more demanding in regard to other economic activities from the financing point of view. The abovementioned specificities cause the need of engagement of significant financial sources in agriculture in short term, which remain tied for a long time in the process of production (Vasiljević, Zakić, 2006).

It is unquestionable that limited sources of financing can be distinguished as one of the key problems for Serbian farmers. Due to the lack of its own funds, farmer usually depends on other sources of funding, such as bank loans, government subsidies etc (Paraušić, Cvijanović, 2006). However, an average farmer in Serbia does not have sufficient level of financial literacy, which significantly hinders the access to additional sources of funding.

When considering the importance of financial literacy, first it is necessary to begin by defining what it means in practice. The terms financial literacy, financial knowledge and financial education often are used interchangeably in the literature and popular media (Huston, 2010).

One of studies in this area indicate that "people who are financially literate are able to make sound financial decisions for themselves and their families, to make informed choices between different financial products and services, to budget and to plan ahead, to build up some savings, to protect themselves against financial risks, to invest prudently (if they have sufficient money) and to understand their rights and responsibilities" (Boekhold, 2016). OECD study "Improving financial literacy" has shown that in the modern globalized world, in the absence of financial education, there is a greater tendency to over-indebtedness and bankruptcy (OECD, 2005).

Traditionally speaking, the need for financial literacy is something that is commonly associated with the adult. The global financial crisis has led to a completely different perception. The crisis has shown that a large number of individuals worldwide have lost entire property as a result of insufficient financial knowledge.

World Bank study from 2011 made a clear recommendation that financial education should be introduced in the formal education system since the lower grades of elementary school. Also, according to the Ben Bernanke - President of the FED (2010), "one of the key lessons of the financial crisis is the importance of financial literacy. In addition to improving the decision-making process about personal finances, teaching pupils about basic economic principles will help them to better understand and easier to cursor over a number of key issues...” (Fabris, Luburić 2017).

It is very important to note that there is also a recent UNICEF study "Child Social and Financial Education". According to UNICEF, as the most important UN organization that deals with children's rights, "promoting financial education and a positive financial 
culture in children and youth is essential to ensuring a financially literate population capable of making informed decisions" (UNICEF, 2013).

Relying on positive experience worldwide and mentioned recommendations of UNICEF, the Ministry of Economy of the Republic of Serbia has decided to introduce entrepreneurship to primary school through numerous projects. This program is still in its infancy and it would be important that other ministries are included in it, which applies particularly to the Ministry of Agriculture of the Republic of Serbia, based on the aspect of increasing the financial literacy of future farmers.

\section{Key issues of financial literacy in Serbian agriculture}

The research in this paper started from the hypothesis that agricultural producers in Serbia do not have a sufficient level of financial literacy, which significantly affects the opportunities of growth and development of agricultural enterprises (Andžić et al., 2016).

In Table 1 is shown the level of managers' training of farmers in the Republic of Serbia. The most of them have only agricultural experience obtained from practice and there is $378,940(60.0 \%)$ of them in the Republic of Serbia according to the Census of agriculture, and the least are educated managers in the field of agriculture. Only 4\% of them finished an agricultural secondary school or college/university in the field of agriculture. Of total number of managers, 35.3\% have finished some other secondary school, college or university that are not associated with the agricultural profession.

Table 1. The level of managers' training of agricultural holdings, 2012

\begin{tabular}{|l|r|r|}
\hline \multirow{2}{*}{} & \multicolumn{2}{|c|}{ Republic of Serbia } \\
\cline { 2 - 3 } & Number of persons & Structure, \% \\
\hline Agricultural experience gained by the practice & 378,940 & 60.0 \\
\hline Course in the field of agriculture & 4,270 & 0.7 \\
\hline Agricultural secondary school & 16,120 & 2.6 \\
\hline Other secondary school & 191,591 & 30.3 \\
\hline Agricultural college or faculty & 8,992 & 1.4 \\
\hline Other college or faculty & 31,639 & 5.0 \\
\hline Total number of managers in AHs & $\mathbf{6 3 1 , 5 5 2}$ & $\mathbf{1 0 0 . 0}$ \\
\hline
\end{tabular}

Source: Census of Agriculture, 2012: Agriculture in the Republic of Serbia, SORS, Book II

Taking into consideration all mentioned data, it can be notice that the educational structure of a manager in agricultural holdings in the Republic of Serbia is extremely unfavourable. On the other hand Table 1 also show that 4,270 managers in agricultural holdings in the Republic of Serbia have attended courses in the field of agriculture, which indicates the existence of a desire for improvement and further education in the field of agriculture (Zakić, Kljajić, 2016).

In the field of agribusiness, education and extension represent the significant factors of business modernization. In support to this conclusion is the confirmed fact that the investments in extension (and agricultural research) make around 40\% of an average 
rate of return, which is much more than other investments in agricultural development (Van den Ban, Hawkins, 1996).

When the financing literacy in agriculture (observed in a wider sense) is taken into consideration, there could be distinguished several key areas that could be the most significant for farmers in Serbia:

1. Agricultural finance and accounting,

2. Agricultural record keeping,

3. Agricultural production and sales planning,

4. Bank loans,

5. Forms of farmers' associations,

6. Commodity exchange.

As a first step, of the most importance in increasing the financial literacy of farmers is training in the field of agricultural finance and accounting. At first, it would imply an explanation of the most important financial terms, such as: fixed and working capital, depreciation, long-term and short-term liabilities, revenues and expenditures, profit and loss, liquidity, solvency, cost-effectiveness, bookkeeping principles etc.

It is important that farmers learn the essentials in different calculation of agricultural products' cost price, which is a precondition of every long-term planning. Very often, farmers in Serbia start a long-term production without calculation of agricultural products' cost price, expected revenues and other elements of simplified business plan. The required level of training in the field of agricultural finance and accounting would be determined by the target group of farmers: farm size, activities, investment plans etc.

Financial cost-benefit analysis of different investment activities, which can be a purchase of expensive equipment or the decisions on mineral fertilizers quantity, is of most importance because the highest yield is not the most profitable at the same time (Živanović et al., 2016).

Of great importance within the financial stage of education is the improvement of knowledge in the field of different incentives (at the state, province and local level) which are available for farmers. The correlation between the financial literacy and success in claiming subsidies can be noticed, first of all, due to the need for filling different supporting documentation that requires basic financial skills.

Beside lack of financial planning, the most of agricultural holdings in the Republic of Serbia do not keep records on work processes that they perform during the period in vegetable production, as on the specific parcels, as well as on the entire production area. The result is a lack of precise data on the implemented agro-technical measures, consumed outputs, quality and quantity of obtained yields and environment at the holding level.

In this respect, of great significance is the Fields Book, which is an instrument (data source) of production management. It is intended for recording the implemented agro- 
technical measures, production cost and the obtained yields on parcels, and records for grown crop, fruit and vegetable cultures. In the Fields Book producers enter data in detail that refers to the performed soil analyses (physical, chemical, mechanical), type of soil, fuel consumption, fertilizing methods and a type of used fertilizer, phytosanitary protection, irrigation method and a norm, as well as all other operations, for every culture and parcel separately. The Fields Book indicates in a way on the literacy of a manager who manages an agricultural holding (Zakić, Kljajić 2016).

Long term production planning requires market analyses. A farmer can anticipate price trends for several different products and select the most favourable sowing structure by using the market information systems like STIPS (Agricultural marketing information system of Serbia). Besides the selection of production, a market analysis plans also determine a time of maturity of products (in crop farming and fruit growing a few days earlier production can make several times higher price of products). ${ }^{5}$ While selling agricultural products, the financial knowledge and proficiency in marketing channels and marketing techniques are important for success of agricultural products sale. Marketing channels have a multiple role on the market of agricultural products, helping in overcoming different discrepancies (such as spatial, informational, territorial, etc), leaving farmers more opportunity to improve their financial knowledge (Nikolić, Popović, 2016).

In terms of limited own financing resources and incentives, it is necessary for farmers to receive education in the field of bank loans. It could imply education in: types of credit/ loan (commercial, subsidized, credits granted on commodity notes as collateral, etc.), types of interest rates (fixed interest rate and variable interest rate), the loan approval procedure at the bank, forms of loan provision (mortgage and pledge), types of interest rates (an effective and nominal interest rate, a reference rate, etc.), payments instruments etc (Zakić, Kljajić, 2016). Limited confidence in the banking sector was formed as a result of high interest rates, relatively small total amount of agricultural credits which leads to high fixed costs of granting and repayment of loans, lack of expertise and experience of banking staff in dealing with agricultural producers but also the lack of experience and expertise of farmers in developing and presenting business plans. In this sense, any program for improving the financial literacy needs to be aimed significantly towards training courses for making business plans (Subić, Kuzman, 2016)

Of great importance is also the increase in knowledge level in the field of association (cooperatives and clusters). Starting from developed countries experience, but also some developing countries, we can conclude that the cooperatives could have significant role in the development of agricultural production.

The cooperative movement in Serbia (before Second World War) has a long and fruitful tradition. After a phase of relative neglect of cooperatives in past decades, today

5 According to an insight into the multi-year price trends of products on the market information systems like STIPS, farmer decides about the time of maturity of products; in which period price is the highest, taking care of increased costs of earlier production and possibly increased risk of production.

EP 2017 (64) 4 (1687-1702) 
cooperatives are facing different challenges. To enable the reestablishment of a healthy and prosperous cooperative sector in the country, a conducive legal framework needs to be introduced and effectively implemented in Serbia. To this goal, Serbia's Law on Cooperatives was officially adopted by the National Assembly (December 2015).

The membership and participation of agricultural cooperatives in Serbia is comparatively low. For example, there were over 1400 agricultural cooperatives registered in the country in 2012 (mostly situated in central Serbia and in the Vojvodina) with over 31,000 members, which represents only a minority of Serbian farmers. As a result, cooperatives' full impact on social inclusion, employment and linkages between producers and modern value chains in the country is yet to be attained.

Besides insufficient cooperative education of farmers in Serbia, there is obvious unsatisfying engagement of academics and the neglect in the educational system at all levels, and especially at university level.

Renewal of cooperatives in the coming period should go towards: (a) the development of specialized cooperatives (agricultural, fruit, vegetable etc.); (b) improvement of production, especially of processing and storage capacities of cooperatives, (c) collaboration with other cooperatives and creation of specialized cooperatives associations, which would in this way, achieve economies of scale and increased market and bargaining power (Popović, Paraušić, 2016).

Agricultural cooperatives could have an important role in the improving the state of financial literacy, although at the moment they have relatively low level of implementation of ICT technologies. Only 80 percent of agricultural cooperatives have a computer, and $20 \%$ of those coops do not have an internet connection (Ševarlić, Nikolić, 2012).

In order to increase financial literacy from the aspect of association, the education of farmers should involve following areas: significance and different forms of association, presentation of impressive results of a cooperative sector in developed countries, a presentation of the new Law on Cooperatives, expected incentives which are often announced in media etc.

Finally, of great importance could be training in the area of commodity exchange and its role in the management of business risk of agricultural enterprises, the instruments of non-standardized futures market (forwards) and standardized futures market of commodity reserves (futures deal and options), the role of a clearing house as a warrantor, the system of pre-harvest financing etc (Zakić et al., 2014). This "advanced level" of education can be important as for small individual farmers as well as for owners and managers of big corporate companies in the field of agribusiness.

It is therefore expected of science to transfer necessary knowledge and skills to agricultural holdings, and by the adoption, they would be in a position to plan more efficiently, organize, fund and manage the production process, save on inputs, produce a greater amount of healthy-safe products respecting the principles of environmental protection, and sell successfully everything manufactured on the local and regional 
markets; in one word, to be able to independently affect the strengthening of their business sustainability.

Unfavourable age structure of farms managers is one of the limiting factors for the improvement of financial and computer literacy on holdings. According to Census of Agriculture data (2012) in the Republic of Serbia, the highest share of family agricultural holdings managers was over 65 years of age and was amounted $32 \%$ of total number of managers. Family agricultural holdings are characterized by devastated and elderly village - about 200,000 family farms have no population younger than 25 years; to about $80 \%$ of these holdings no active farmers (Zakić, Zakić, Mirović, 2014)

There is no easy answer when it comes to motivating young people to stay or return to the rural area. There could be considered variety of projects, but of the great importance are potential special subsidies for those farms that have a younger workforce. In this sense, of great importance are programs to increase the financial literacy level of young people and even school children. As mentioned, the Ministry of Economy has decided to introduce entrepreneurship to primary school through numerous projects. With the support of Ministry of Agriculture, it would be significant to further develop those ideas with agricultural entrepreneurship educations, especially in rural areas.

\section{Methodology}

In this paper was used the following methodology:

- Desk research method,

- Interviews with the leading experts in this field,

- Review of domestic and foreign literature,

- Survey that included farmers, scientific-research institutions in the field of agroeconomy, agricultural extension (AE) and the policy makers in the field of education in an agricultural sector.

\section{Results and discussion}

A field research - a survey was carried out in the period from February to March in the year 2017, which has included:

1. Farmers,

2. Scientific-research institutions in the field of agro-economy,

3. AEs,

4. The policy makers in the field of education, the Ministry of Agriculture and Environmental Protection (MAEP) and the Ministry of Education, Science and Technological Development of the Republic of Serbia (MESTD).

1. Results of the farmers'survey

For the purpose of this survey 30 holders of family agricultural holdings were interviewed. These were the questions: 
- Do you have all necessary financial skills that I need?

Graph 1. Possession of financial skills

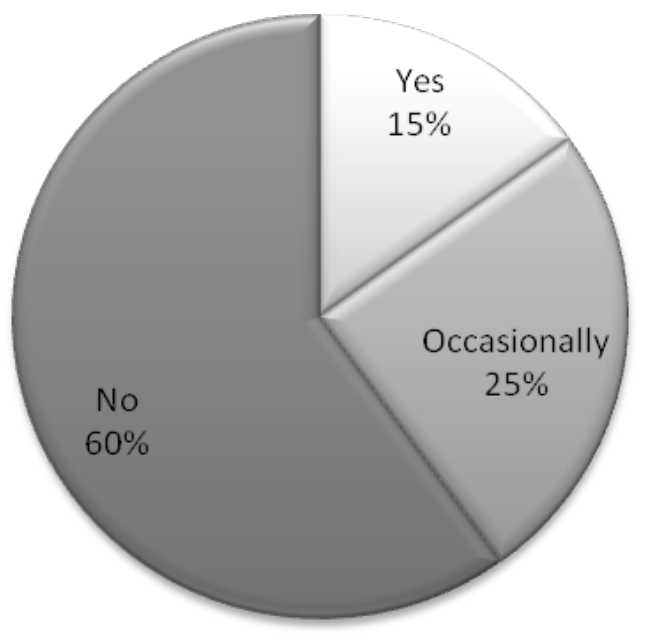

Source: author's calculation

- Do you keep a record on costs and expenditures in a holding?

Graph 2. Existence of record on costs and expenditures in a holding Ocasuanaly

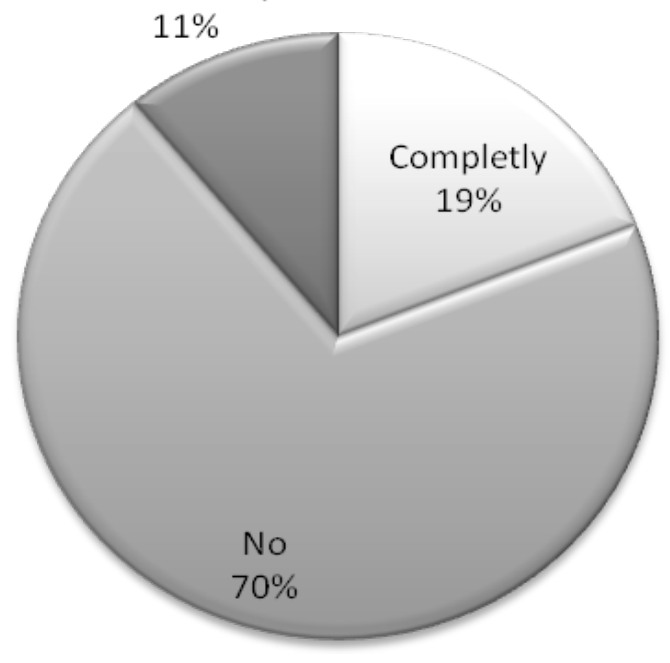

Source: author's calculation

- Do you perform an investment analysis before you invest? 
Graph 3. Performance of investment analysis before you invest

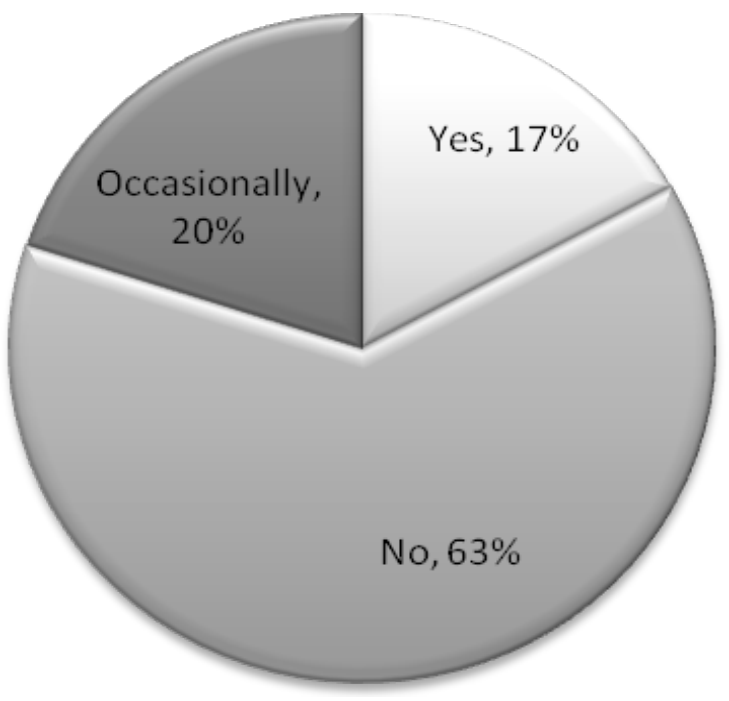

Source: author's calculation

- Do you use STIPS or some other data on multi-year price trends of a product or reports and forecasts on price trends while you plan production?

Graph 4. Use of STIPS or some other data on multi-year price trends of a product or reports and forecasts on price trends while you plan production

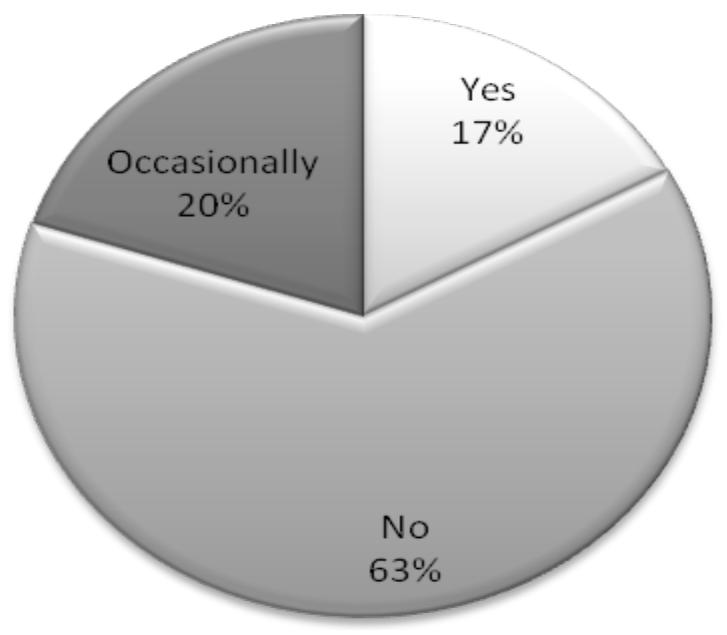

Source: author's calculation

- Did you attend education in the field of financial knowledge and records on an agricultural holding? 
Graph 5. Attendance on education in the field of financial knowledge and records on an agricultural holding

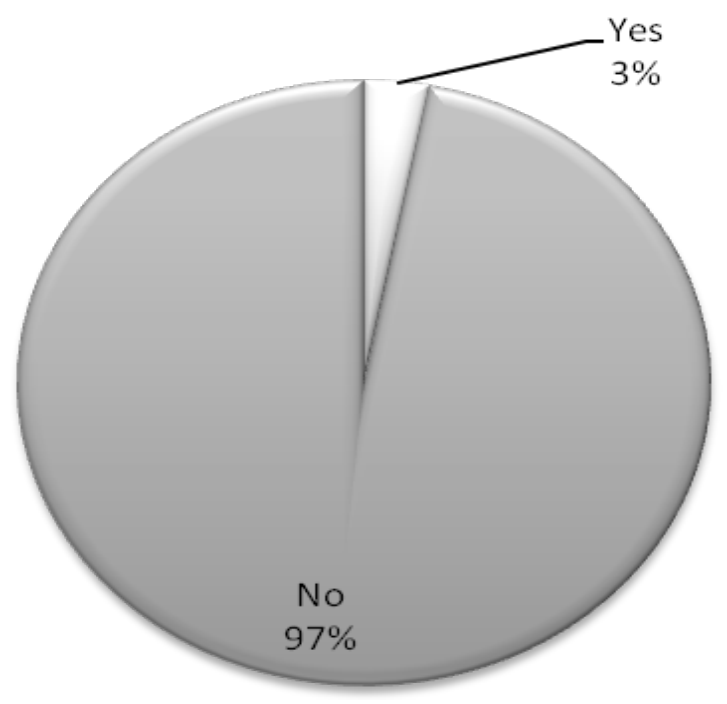

Source: author's calculation

- Suggestions for the improvement of financial knowledge on agricultural holdings?

* Organizing continuous training by the AEs.

* Support of consultants in the field concerning the investment analyses.

2. Results of a survey conducted by a scientific-research institution in the field of agroeconomy

For the purpose of this research were interviewed the Faculty of Agriculture in Zemun, Institute of Agricultural Economics and the Institute for Economic Research. The questions were as follows:

- Evaluation of the farmers' financial knowledge?

The possible responses were: good, moderate and poor, and all of respondents were answered that knowledge in the field of finances was pretty poor.

- Is there any training for individual farmers in your scientific institution?

All respondents answered negatively.

- Are there any suggestions for the improvement of financial knowledge on agricultural holdings?

* Continuous training of farmers in the field of finances and records on a holding by the state authorities in which the scientific institutes and faculties would be included.

* Linking the right of using some subsidies and done training of farmers.

* Improvement of coordination in planning the research and education program 
among the policy holders in this field (MAEP, MESTD, Provincial Secretariat for Agriculture, Forestry, Water Management and Science).

* Unified publishing of educational material and the scientific research results funded by the budgetary funds or donations.

* Forming a regional database with an educational material and the scientific research results among countries in the region (e.g. EU NORDIC system).

\section{Results of a survey conducted by the AEs}

For the purpose of this research, eight AEs were interviewed. The questions were as follows:

- Is there a need for the improvement of farmers' financial knowledge?

All respondents answered that there was a great need for the improvement of farmers' financial knowledge.

- Are there any suggestions for the improvement of financial knowledge on agricultural holdings?

* Introduction of a continuous training of farmers in the field of finances and records on a holding by the AEs.

* Introduction of a continuous training of agro-consultants in the field of finances and records on a holding by the AEs.

* Employment of a large number of consultants of agro-economic profession.

* Linking the right of using some subsidies and finished training of farmers.

* Unified publishing of an educational material and the scientific research results funded by the budgetary funds or donations.

4. The survey results of policy holders in the field of education, the Ministry of Agriculture and Environmental Protection (MAEP) and the Ministry of Education, Science and Technological Development of the Republic of Serbia (MESTD).

- Is there a need for the improvement of farmers' financial knowledge?

The respondents answered that there was a great need for the improvement of farmers' financial knowledge.

- Is there any continuous training by your institution in the field of farmers' financial knowledge?

The respondents answered negatively, but with a note that MAEP has organized training related to the improvement of financial literacy and record on agricultural holdings in 2016.

- Are farmers involved in planning the scientific projects and educations?

MAEP performs interviewing of consultants, but not farmers as well, through the state extension service while planning educations for the following year. In planning educations and scientific researches none of institutions perform the public hearings with farmers. 
- Are there any suggestions for the improvement of financial knowledge on agricultural holdings?

* Continuous training of farmers in the field of finances and records on a holding by the state authorities in which the scientific institutes and faculties would be involved.

* Linking the right of using some subsidies and finished training of farmers.

* Improvement of coordination in planning the research and education program among the policy holders in this field (MAEP, MESTD, Provincial Secretariat for Agriculture, Forestry, Water Management and Science).

* Unified publishing of an educational material and the scientific research results funded by the budgetary funds or donations.

\section{Discussion}

According to the conducted research, we can say that the great importance for successful business in an agricultural sector is the financial knowledge of farmers.

The conducted researches at the level of farmers' financial knowledge, as well as the Census of Agriculture results from 2012, show a very low level of financial knowledge and records on holdings. Low level of education on holdings disables a selection of the optimal investments, whether it is about a significant investment in purchasing equipment or daily financial decisions which dosage of fertilizer to apply. Holdings with a low level of financial knowledge claim subsidies more difficult, due to a need for making the investment analyses, which are the subject of subsidies and the other one, while planning production without financial knowledge planning is done "randomly" - instead of observing the price trends in previous years, as well as the projection of future price trends. Management of an agricultural holding's business risk should base on the scientifically proven techniques, aiming to decrease the risk of insolvency and bankruptcy of a holding. The financial knowledge in the field of market and trade in agricultural products are necessary in order to sell successfully products, by which would increase the bargaining power of farmers and improve the sale of products. In regard to the realization of an education program in the field of financial knowledge, the MAEP has realised a program of farmers' education in the year 2016 based on the financial literacy, but this program hasn't been continued in 2017.

It is necessary to train farmers continuously in the field of finances and records on holdings by the state authorities in which would be involved scientific institutes and faculties, but also the continuous training of agricultural consultants.

Additional employment of experts of agro-economic profession in the AEs would be very important since there are a small number of experts in this field and a large number of agricultural holdings.

Linking the right of using some subsidies with finished course would contribute to a higher 
farmer's attendance to AEs training (usually winter schools). ${ }^{6}$

In the Serbia several institutions have educational and scientific programs in agriculture i.e. Ministry of Agriculture, Ministry of Science, Province of Vojvodina Secretariat for Agriculture, Province of Vojvodina Secretariat for Science. This programs are not fully coordinated between this institutions and with aim to avoid overlapping of program' subject it could be advised to establish coordination body within the Ministry of science to coordinate educational and scientific programs between those four institutions.

Unified publishing of an educational material and the scientific research results, financed by budgetary funds and donations, is of great importance. In this way, it could provide farmers and professional public an insight into the educational material and the scientific research results on one place.

Uniting all scientific and educational material in a regional database that is available to the public is the practice in EU for countries which have similar agro-ecological conditions and especially similar speaking area.

\section{Conclusions and recommendations}

It is evident that an average farmer has insufficient level of financial literacy, which significantly complicates their business. As a first step in overcoming this problem, it is inevitable to determine the primary educational fields. However, it is important to mention that the education program cannot be the same for every farmer.

Financial knowledge enables the optimal use of financing sources and the decrease of risk of holdings' liquidity.

The possibility of claiming the measures of support in agriculture increases by the application of modern achievements and knowledge in the field of finances, which is especially significant for using the EU pre-accessing funds.

In the sale of agricultural products, the financial knowledge, proficiency in marketing channels and marketing techniques are important for successful sale of agricultural products.

The implemented research of farmers' financial knowledge level, as well as the results of Census of Agriculture in 2012, show a low level of financial knowledge and records on holdings. Low level of education on holdings disables a selection of the optimal investments. Holdings with a low level of financial knowledge claim subsidies more difficult, due to a need for making the investment analyses.

According to the conducted research can be given the following recommendations:

- Continuous implementation of education related to the farmers' financial literacy.

- Inclusion of institute and faculties in continuous training related to financial

6 Due to a small number of consultants, in this way by attending the group trainings, would increase the efficiency of AEs.

EP 2017 (64) 4 (1687-1702) 
education.

- Continuous training of consultants and the employment of experts of agro-economic profession in the AEs.

- Linking the right of using some subsidies with finished courses would contribute to the higher farmer's attendance to AEs training.

- Introduction of training programs in the field of entrepreneurship already at the level of primary school.

- Improvement of coordination in planning the research and education program among the policy holders in this field (MAEP, MESTD, Provincial Secretariat for Agriculture, Forestry, Water Management and Science). Currently the coordination is not completely established and there is a possibility of overlapping the projects, which could be improved through the establishment of a coordinating body within the ministry authorized for science by all involved institutions.

- Unified publishing of an educational material and the scientific research results, which are financed by budgetary funds and donations.

- Establishment of a regional database in which would be available and in one place all published scientific and educational material of the region countries.

\section{Literature}

1. Agricultural Census (2012). Agriculture in the Republic of Serbia, RZS, Book II (Popis poljoprivrede 2012. Poljoprivreda u Republici Srbiji, RZS, knjiga II).

2. Andžić, S., Rajković, M., Ćosić, M. (2016): Nefinansijski aspekti poslovanja kao faktori razvoja preduzetništva, Oditor, Vol. 2, No. 2, pp. 7-17.

3. Boekhold, H. (2016). Financial Literacy to Facilitate Access to Finance in Eastern Africa - Final Report, Café Africa http:/www.globalcoffeeplatform. org /assets/files/Financial-Literacy-training-tools-and-materials-for-Africancoffee-farmers.pdf (Available: May 1st 2017).

4. Fabris, N., Luburić, R. (2017). Finansijsko obrazovanje dece i omladine, ISBN 978-86-7956-106-0, Heraedu, Belgrade.

5. Huston, S. (2010). Measuring Financial Literacy, The Journal of Consumer Affairs, Vol. 44, No. 2, pp. 296-316, USA.

6. Nikolić, M., Popović, A. (2016). Specifics of Marketing in Overcoming Discrepancies on the Market of Agricultural Products, Marketing, Volume 47; Issue 1, pp. 21-28, Belgrade.

7. OECD (2005): Improving financial literacy, ISBN 9789264012561, OECD, Paris.

8. Paraušić, V., Cvijanović, D. (2006). Kreditiranje poljoprivrednih proizvođača u Srbiji u periodu 2004-2006. godina - potrebe $i$ mogućnosti. Economics of Agriculture, Vol. 53, No 1, Institute of Agricultural Economics, pp. 49-61, Belgrade. 
9. Popović, V., Paraušić, V. (2016). Unapređenje trgovanja u poljoprivredno prehrambenom sektoru Srbije, ISBN 978-86-6269-053-1, Unapređenje finansijskih znanja i evidencije na poljoprivrednim gazdinstvima u Republici Srbiji - monografija, Institute of Agricultural Economics, pp. 23-54, Belgrade.

10. Serbia's Law on Cooperatives, Official Gazette RS, No. 112/15. (Zakon o zadrugama, Službeni glasnik br. 112/15).

11. Serbia's Law on Financing and Provision of Financing of Agricultural Production, Official Gazette RS, No. 128/14. (Zakon o finansiranju i obezbeđenju finansiranja poljoprivredne proizvodnje, Službeni glasnik br. 128/14).

12. Ševarlić, M., Nikolić, M. (2012). Standpoints of the directors of co-operatives and members about agricultural co-operative sector in Serbia, Monograph, SAAE, Ministry of agriculture, trade, forestry and water management of the Republic of Serbia, pp. 1-64, Belgrade.

13. Subić, J., Kuzman, B. (2016). Uputstvo i model za izradu biznis plana na poljoprivrednim gazdinstvima, ISBN 978-86-6269-053-1, Unapređenje finansijskih znanja i evidencije na poljoprivrednim gazdinstvima u Republici Srbiji - monografija, Institute of Agricultural Economics, pp. 95-128, Belgrade.

14. UNICEF (2013). Child Social and Financial Education, https://www.unicef. org/publications/files/CSFE_module_low_res_FINAL.pdf (Available: May 1st 2017).

15. Van den Ban, A.W., Hawkins, H.S. (1996). Agricultural Extension, ISBN 063204053X, Blackwell Science, UK.

16. Vasiljević, Z., Zakić, V. (2006). Finansiranje agroprivrede Srbije u uslovima tranzicije, Društvo ekonomista Beograda, Ekonomski vidici, XI, broj 2, pp. 341-353, Belgrade.

17. Zakić, V., Kljajić, N. (2016). Analiza stanja finansijske pismenosti poljoprivrednih proizvođača i modeli finansiranja poljoprivredne proizvodnje u Republici Srbiji, ISBN 978-86-6269-053-1, Unapređenje finansijskih znanja i evidencije na poljoprivrednim gazdinstvima u Republici Srbiji - monografija, Institute of Agricultural Economics, pp. 3-22, Belgrade.

18. Zakić, V., Kovačević, V., Ivkov, I., Mirović, V. (2014). Importance of public warehouse system for financing agribusiness sector, Economics of Agriculture, No 4. Vol. 61, Institute of Agricultural Economics, pp. 929-943, Belgrade.

19. Zakić, V., Vasiljević, Z. (2013). Uspostavljanje tržišta robnih derivata u funkciji unapređenja poslovanja agrosektora u Srbiji, Društvo ekonomista Beograda, Ekonomski vidici, 18(1), pp. 49-61, Belgrade.

20. Zakić, V., Zakić, Z., Mirović, V. (2014). Udruženo porodično gazdinstvo u agro-ruralnoj privredi Srbije kao generator zapošljavanja, Ekonomski vidici - Tematski broj „Zapošljavanje i privredni razvoj Srbije”, godina XIX, br. 2-3, 
Društvo ekonomista Beograd, pp. 185-198, Belgrade.

21. Zakić, Z. (2013). Zadrugarstvo i ruralni razvoj: povezane teme u procesu evrointegracija Srbije, Tematski zbornik "Stanje i perspektiva zadrugarstva", broj.3, DAES, pp. 27-52, Belgrade.

22. Živanović, Lj., Kovačević, V., Subić, J., Jeločnik, M., Zubović, J. (2016). Economic cost - effectiveness of different nitrogen rates application in the production of corn hybrids of different FAO maturity groups on brown forest soil (Euteric Cambiosol), Journal Custos e Agronegócio, vol. 12, no. 4 (OctoberDecember), pp. 279-294, Brazil.

\section{ZNAČAJ FINANSIJSKE PISMENOSTI ZA POLJOPRIVREDNA GAZDINSTVA U SRBIJI}

Vladimir Zakić', Vlado Kovačevićs ${ }^{8}$ Jelena Damnjanovićc

\section{Rezime}

Cilj rada je analiza značaja posedovanja finansijskih znanja, nivoa finansijskih znanja poljoprivrednika, kao i analiza sa predlogom mera za unapređenje finansijskih znanja na poljoprivrednim gazdinstvima.

Prema rezultatima rada nivo finansijskih znanja poljoprivrednika je nizak, a na državnom nivou nije uspostavljena zadovoljavajuća edukacija poljoprivrednika u ovoj oblasti. Neophodno je uspostaviti kontinuirane programe edukacije u ovoj oblasti preko poljoprivrednih stručnih službi; na državnom nivou neophodno je unaprediti koordinaciju različitih državnih organa koji sprovode program edukacije $u$ poljoprivrednom sektoru, kao i rezultate nauke i edukacioni materijal učiniti dostupnim poljoprivrednicima.

Kada se razmatra značaj finansijske pismenosti, ona se obično analizira iz perspektive odraslih ljudi. Međutim, nedavna istraživanja ukazuju na značaj povećanja finansijske pismenosti već na nivou mladih i dece. Ovaj teorijski koncept je trenutno prihvaćen u aktivnostima Vlade Republike Srbije. U tom smislu, Ministarstvo privrede je odlučilo da kroz brojne projekte otpočne promociju preduzetništva u osnovnim školama.

Ključne reči: finansijska znanja, savetodavna služba, modeli finansiranja, poljoprivreda.

7 Vanredni profesor dr Vladimir Zakić, Univerzitet u Beogradu - Poljoprivredni fakultet, Nemanjina 6, 11080 Beograd-Zemun, e-mail: zakic@agrif.bg.ac.rs

8 Dr Vlado Kovačević, naučni saradnik, Institut za ekonomiku poljoprivrede, Beograd, e mail: vlado k@iep.bg.ac.rs

9 Dr Jelena Damnjanović, profesor strukovnih studija, Visoka poslovna škola strukovnih studija, Novi Sad, e mail: $\underline{\text { skola@,vps.ns.ac.rs }}$ 
ECONOMICS OF

AGRICULTURE

\section{CONTENT}

1. Adriana Radosavac, Desimir Knežević

ECONOMIC IMPORTANCE OF USE

OF PESTICIDES IN WHEAT PRODUCTION . . . . . . . . . . . 1323

2. Berhe Gebregewergs, Muuz Hadush

DOES CLIMATE CHANGE AFFECT PRICE OF VEGETABLES:

EVIDENCE FROM TIGRAI, NORTHERN MOST ETHIOPIA. . . . .1335

3. Grujica Vico, Aleksandra Govedarica-Lučić, Zoran Rajić, Radomir Bodiroga, Ivan Mičić, Silvija Zec Sambol, Marija Mičić

MULTI ATTRIBUTE ASSESSMENT APPROACH

IN VEGETABLE PRODUCTION . . . . . . . . . . . . . . 1355

4. Igor Trandafilović, Vesna Conić, Aleksandra Blagojević

IMPACT OF DEMOGRAPHIC FACTORS ON

ENVIRONMENTALLY CONSCIOUS PURCHASE BEHAVIOUR. . .1365

5. Imre Milán Harcsa

STUDY ON THE POTENTIAL OF SUBCONTRACT

PALINKA DISTILLATION . . . . . . . . . . . . . . 1379

6. Jelena Andrašić, Vera Mirović, Nada Milenković, Branimir Kalaš, Miloš Pjanić

IMPACT OF TAKEOVER PROCESS ON EMPLOYEES -

EVIDENCE FROM FOOD, RETAIL AND FINANCIAL SECTOR . . .1393

7. Jelena Birovljev, Danilo Đokić, Bojan Matkovski, Žana Kleut

ECONOMIC PERFORMANCES OF AGRICULTURE

OF CEFTA AND FORMER CEFTA COUNTRIES . . . . . . . . . . 1413

8. Jelena Marković, Svetlana Stevović

SUSTAINABILITY OF CHEMICAL SOIL QUALITY

IN SOUTHERN MORAVA RIVER VALLEY

IN CORELLATION WITH THE FLOODING $\ldots \ldots \ldots \ldots \ldots$ 
9. Mile Peševski, Zoran Milovančević

THE CHANGES IN THE USAGE OF AGRICULTURAL LAND

IN EASTERN REGION OF REPUBLIC OF MACEDONIA

BETWEEN $1991-2030 \ldots \ldots$. . . . . . . . . . . . . . . . . . . . . . .

10. Odjuvwuederhie Emmanuel Inoni, 'Oraye Dicta Ogisi, Felix Odemero Achoja

PROFITABILITY AND TECHNICAL EFFICIENCY IN HOMESTEAD

CATFISH PRODUCTION IN DELTA STATE, NIGERIA . . . . . . . 1449

11. Olja Munitlak - Ivanović, Jovan Zubović, Petar Mitić

RELATIONSHIP BETWEEN SUSTAINABLE DEVELOPMENT AND

GREEN ECONOMY - EMPHASIS ON GREEN FINANCE

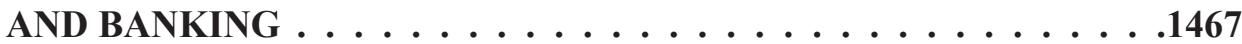

12. Petar Munćan, Dragica Božić

FARM SIZE AS A FACTOR OF EMLOYMENT AND INCOME

OF MEMBERS OF FAMILY FARMS . . . . . . . . . . . . . 1483

13. Rade Popović, Mira Kovljenić

EFFICIENCY OF WHEAT PRODUCTION ON FARMS

IN THE REPUBLIC OF SERBIA . . . . . . . . . . . . . . . . . . . . . . . . .

14. Radovan Damnjanović, Snežana Krstić, Milena Knežević, Svetislav Stanković,

Dejan Jeremić

THE DISCRIMINANT ANALYSIS APPLIED TO THE

DIFFERENTIATION OF SOIL TYPES . . . . . . . . . . . . 1513

15. Slavica Otović, Dunja Demirović, Kristina Košić, Aleksandra Vujko

FOSTERING ENTERPRENUERSHIP AT HIGH SCHOOLS:

A CASE OF RURAL AREAS IN VOJVODINA (SERBIA) . . . . . . .1523

16. Vladimir Ilić, Ivan Bauer, Anastazija Tanja Đelić, Aleksandar Nešković

INSTITUTIONAL SUPPORT FOR STRENGTHENING

ENTREPRENEURSHIP IN AGRICULTURAL PRODUCTION

OF THE REPUBLIC OF SERBIA . . . . . . . . . . . . . . . . . . . . . . . .

17. Boro Krstić, Zorica Vasiljević, Miroslav Nedeljković

INSURANCE CONTRACT AS THE BASIS FOR THE SAFETY OF

AGRICULTURAL PRODUCERS IN THE REPUBLIC OF SRPSKA • . 1555

18. Dejan Sekulić, Aleksandar Petrović, Vladimir Dimitrijević

WHO ARE WINE TOURISTS? AN EMPIRICAL INVESTIGATION

OF SEGMENTS IN SERBIAN WINE TOURISM . . . . . . . . . . . . . 
19. Milan Beslać, Ćorić Goran

FINANCIAL AND PRODUCTION ASPECTS OF GENETICALLY MODIFIED ORGANISMS $\ldots \ldots \ldots \ldots \ldots \ldots \ldots \ldots \ldots$

20. Mlađan Maksimović, Darjan Karabašević, Miodrag Brzaković, Pavle Brzaković THE EFFECTS RESULTING FROM THE APPLICATION OF THE CONCEPT OF THE SUSTAINABLE DEVELOPMENT OF RURAL TOURISM ON STARA PLANINA . . . . . . . . . . . . . . . .1595

21. Vesna Popović, Predrag Vuković, Milivoje Ćosić FOOD SAFETY AND QUALITY POLICY IN THE REPUBLIC OF SERBIA . . . . . . . . . . . . . . . . 1607

22. Radovan Pejanović, Danica Glavaš-Trbić, Mirela Tomaš-Simin PROBLEMS OF AGRICULTURAL AND RURAL DEVELOPMENT IN SERBIA AND NECESSITY OF NEW AGRICULTURAL POLICY . . . .1619

23. Saša Marković, Slavoljub Vujović, Aleksandar Damnjanović MARKETING AND HIGHER EDUCATION CONDITION IN SERBIA . . . . . . . . . . . . . . . . 1635

24. Semir Vehapi, Marina Milanović THE EFFECT OF MARKET ORIENTATION ON BUSINESS PERFORMANCE OF SERBIAN ORGANIC PRODUCERS . . . . . 1651

25. Suad Bećirović, Šemsudin Plojović, Enis Ujkanović, Senadin Plojović CHALLENGES AT STARTING AN AGRIBUSINESS IN THE HILLY MOUNTAINOUS REGIONS OF SOUTHWEST SERBIA . . . . . . . .1669

26. Vladimir Zakić, Vlado Kovačević, Jelena Damnjanović SIGNIFICANCE OF FINACIAL LITERACY FOR THE AGRICULTURAL HOLDINGS IN SERBIA . . . . . . . . . . 1687

27. Željko Bjelajac, Marijana Dukić Mijatović, Željko Vojinović PROTECTION OF LAND IN THE REPUBLIC OF SERBIA AND ECOLOGICAL SECURITY WITH REGARD TO STRATEGIC AND LEGAL FRAMEWORKS . . . . . . . . . .1703 